Mayela Zambrano*

\title{
Latinas for Trump Analysis of Processes of Identification and the Use of Narratives to Construct Subject-Positions
}

\author{
https://doi.org/10.1515/soprag-2018-0004
}

\begin{abstract}
The public and commercial spheres constantly address the largest ethnic minority in the United States, people with ancestry or from a Latin American country, as a homogenous group under the ethnopolitical terms "Latinos," "Hispanics," and even "Mexicans." This panethnic view, and the negative stereotypes associated with it, was especially visible during the 2016 presidential election. While the majority of Latinos found Donald Trump's remarks on "Mexicans" offensive to the Latin community as a whole, a large number of people still supported his opinions, even those belonging to the "Latino" community. Even more so, women of Latino heritage still supported a nominee that went against their own advance in society given his constant misogynistic comments. In this essay, I analyze the groundings for this apparent contradiction in the preference for said candidate. I argue that these women's political preference is a tool with which they build their identity in the U.S. Besides, I explore the ways in which individuals linguistically construct their own identity in three ways (i) by actively doing the identification instead of merely receiving it by an unknown agent; (ii) by choosing the self-representation of their preference, and (iii) by finding commonalities and bonding with other individuals they deem part of their group. Through this approach, I analyze semiotic processes, such as intertextuality, use of pronouns, and discourse alignment, that are used to construct identifications of the self that go beyond imposed categories, such as gender and ethnicity.
\end{abstract}

Keywords: identity construction, semiotics, subject-positioning, sociocultural linguistics, US Latinos

Resumen: Las esferas públicas y comerciales de los Estados Unidos constantemente tratan a la minoría étnica más grande del país, aquellas personas con ascendencia o provenientes de un país latinoamericano, como un grupo homogéneo, agrupándolos bajo los términos etnopolíticos de "latinos”, "hispanos”

*Corresponding author: Mayela Zambrano, Spanish and Portuguese, University of lowa College of Liberal Arts and Sciences, lowa City, IA, USA, E-mail: mayela-zambrano@uiowa.edu

Ә Open Access. (C) 2018 Zambrano, published by De Gruyter. (cc) BY-NC-ND This work is licensed under the Creative Commons Attribution-NonCommercial-NoDerivatives 4.0 License. 
o incluso "mexicanos". Esta visión panétnica, y los estereotipos negativos asociados a ella, fue particularmente visible durante las elecciones presidenciales del 2016. Aunque la mayoría de latinos opinaba que los comentarios de Donald Trump sobre los "mexicanos" eran ofensivos para toda la comunidad latina, un gran número de personas siguió estando de acuerdo con las opiniones del candidato, incluso aquellos que pertenecen a dicha comunidad. Incluso algunas mujeres con ascendencia latina continuaron apoyando a un candidato que va en contra de sus propios intereses, dados sus constantes comentarios misóginos. En este ensayo analizo las razones de esta aparente contradicción en la defensa de este candidato presidencial. En este trabajo afirmo que las preferencias políticas de estas mujeres se convierten en una herramienta a través de la cual construyen su identidad en los Estados Unidos. Además, se exploran las maneras en las que los individuos construyen su identidad lingüística de tres formas (i) al crear su propia identificación de forma activa, en lugar de simplemente recibirla de un agente desconocido; (ii) al escoger la auto representación de su preferencia y (iii) al buscar características compartidas y crear conexiones con otros individuos que consideran parte de su grupo. A través de este enfoque, analizo procesos semióticos, tales como la intertextualidad, el uso de pronombres y el alineamiento del discurso, que han sido utilizados para construir identificaciones de sí mismo que van más allá de categorías impuestas, como lo son las categorías de género y de etnicidad.

Palabras clave: Construcción de la identidad, semiótica, posicionamientos del sujeto, lingüística sociocultural, latinos en Estados Unidos

\section{Introduction}

In the 2016 presidential campaign, president-elect Donald Trump articulated several offensive comments and threats against different ethnic groups, amongst which were the largest ethnic group in the U.S., the Hispanics. The then candidate was also known for his misogynistic speech and the lewd comments directed towards women that were portrayed in national television. Apart from those who do not share Trump's opinions regardless of their gender or ethnicity, it would be obvious to expect that those who felt personally attacked would not have supported his journey to presidency. However, this was not the case. Polls show that at least $53 \%$ of white women voted for Trump, as well as at least $26 \%$ of Hispanic women (Levinson, 2016).

In this essay, I analyze the groundings for this apparent contradiction in the preference for a candidate that will most likely not work towards Hispanic women's benefit. I argue that these women's political preference is a tool with 
which they build their identity in the U.S. Based on current research on identity, I explore the ways in which individuals construct their own identity in three ways (i) by actively doing the identification instead of merely receiving it by an unknown agent; (ii) by choosing the self-representation of their preference, and (iii) by finding commonalities and bonding with other individuals they see as part of their group. Through this approach, I analyze semiotic processes, such as intertextuality, use of pronouns, and discourse alignment, that are used to construct particular identifications of the self that go beyond imposed categories, such as gender and ethnicity.

\section{Theoretical framework}

The assumption that ethnicity is an unchangeable and intrinsic characteristic of individuals has been discussed and challenged previously in the literature, with researchers demonstrating that this is not the case (Bucholtz 2011, Hall, 2012 Woolard, 2008). I aim to contribute to this area of research by studying how US Latinas navigate the impositions in commercial and public spheres that are tied to their ethnic identity and gender. In the United States, anyone affiliated, related or in touch with Latin America or Spain is categorized as Hispanic/ Latino $^{1}$ (Acosta-Belén \& Santiago, 1998). This is especially noticeable in commercial spheres, where the population represents a growing consumer group, and in politics, where every four years the politicians become concerned with the Latino vote. This paper examines not only how such impositions are constructed, but also the way in which some people choose to navigate these expectations and impositions through language.

Some authors, like Brubaker (2004), argue that the discussion on identity within academic research has failed to achieve a real understanding of individuals' identity because of the conceptual tools with which researchers work. Thus, Brubaker (2004) proposes three different concepts that better shape research on identity by disentangling the perspectives from which identity is analized. The first one, "identification and categorizaton" (Brubaker, 2004, p. 41), should be used as an active term that forces the researcher to determine who is doing the action of identifying and categorizing. The second one, "selfrepresentation and social location” (p. 44), includes how individual and

1 Dávila (2001) noticed a trend in her research. People from Hispanic origins feel that the term Hispanic is more institutionalized and that the term Latino better reflects their cultural associations. However, the preference varies, and it is not the case for everyone. 
collective action is governed by individual understandings of the self. Brubaker adds a final group of notions that, according to his view, should be studied separatedly from the aforementioned. These notions/concepts, "commonality, connectedness, groupness" (p. 46), should make specific reference to the sense of belonging to a set group, including the feeling of difference or antipathy to outsiders. In this analysis, I make use of these conceptuals tools for a more comprehensive approach to the active processes of identity construction. Through the analysis of semiotic processes such as the use of pronouns, the reproduction of prevalent language ideologies, and the positioning of the self in speech, we can reach a better understanding of how the construction of individual and collective identity is in constant development. The data for this analysis has exposed two mainstream discourses that help in the construction of the panethnic view of US Latinas: the Latino Threat (Chavez, 2008), and the hypersexualization of the Latina Body (Mendible, 2007). These narratives are considered mainstream for several reasons. First, the views on Hispanic population have never ceased to portray immigration as a threat to national security; secondly, Latinas' sexual behavior has been highly stigmatized and considered hypersexual according to normative standards. Both of these discourses became more public during the presidential campaign of 2016. Having a candidate that reproduced these narratives publicly, and seeing the large number of sympathizers that followed the candidate's lead, made researchers aware that these issues were far from being a thing of the past.

The first mainstream discourse regarding US Latinos emphasizes that they pose a threat to the development and national security of the country. In general, as Chavez (2008) suggests, the Latino Threat has been pushed forward as a discourse strategy that takes premises and grants them as true. This ideology claims that

Latinos, whether immigrant or U.S.-born, are a homogeneous population that somehow stands apart from normal processes of historical changes. They are immutable and impervious to the influences of the larger society and thus are not characterized as experiencing social and cultural change ... (p. 41)

Thus, Latinos are ideologically indexed, iconized, and positioned according to mainstream values. The differences among cultures, countries, customs, and even languages, undergo erasure. This discourse is manifested as well in many areas of the language spoken in the U.S., and has been vastly studied by researchers in linguistics, e.g. Mock Spanish, i. e., appropiation and use of Spanish only in satirical, racialized ways (Hill, 2008), and the Brown Tide metaphors, i.e., use of representations and associations that constitute social values (Santa Ana, 2002). Researchers continue to indicate that the prevalence 
of these narratives shape the values of modern American society. In particular, Dávila's work (2001) on Latino's marketing popularity and constitutive of US Latinidad that explores how the marketing industry affects "both their public recognition and continued invisibility in US society” (Dávila, 2001, p. 3).

The second prevalent mainstream discourse follows from particularly conservative and religious discourses against the female body. Chavez (2008) states that "reproduction, as an object of discourse, is an ideological concept that defines normative fertility levels (white women's) and their opposite: the nonnormative, stigmatized, 'high-fertility' of Latinas and the sexual behavior that produced it” (p. 74). Mainstream representation of US Latinas focus on high birth rates that shift demographics or on how Jennifer Lopez is "sexually and financially excessive" (Molina Guzman, 2007, p. 118), while at the same time being a source of white heterosexual desire. The way US Latinas navigate the mainstream constructions of "the Latina body" (Mendible, 2007, p. 1) as a "historically contingent, mass-produced combination of myth, desire, location, marketing and political expedience" is the object of this study.

At the same time, the antiabortion discourse in the United States is the result of a conservative and violent narrative aimed to regulate the female body. Abortion providers and patients were subjected to much violence before the 1994 FACE Act. This law made it a federal crime to interfere with access to clinics that provided health services. However, the antiabortion movements have never entirely ceased their battle to overrule Roe v. Wade (1973), a decision that overturned state abortion regulations and "expanded the fundamental right of privacy” (Schoen, 2015, p. 11), seen as the precedent for legal abortion. Much of the narrative surrounding abortion has been based on misconceptions, and has adopted telling terminology that portrays a fetus as a human being from its conception. The terms partial birth abortion, late-term abortion and pro-life are all based on wrong understandings of proceedings used to remove a fetus from the uterus prior to viability, i. e., "the point at which independent life outside the uterus becomes possible" (Schoen, 2015, p. 22).

Both of these discourses mentioned above, and the ideologies behind them play a major role in social categorization among individuals. Studies in sociology and cognitivist theories have demonstrated the tendency to favor members of one group against another, e. g. "the mere perception of belonging to two distinct groups - that is, social categorization per se - is sufficient to trigger intergroup discrimination favoring the in-group" (Tajfel and Turner (year), in Brubaker, p. 74). Therefore, within the framework of the prevalent mainstream discourses in the U.S., Latinas are construed as being the out-group, not part of the real in-group, the American. The formation of these in and out-groups are not simply based on mere categories assigned to individuals by their skin color, 
their language or their gender. Individuals navigate categories beyond the binaries based on different contextual needs that are in constant change due to the fluidity of our self-representations.

\section{Methodology}

The methodology used in this research is defined as Critical Discourse Analysis through the use of netnography research. Netnography (Kozinets, 2015) has been recently advocated from the field of mass communication to study the impact of marketing and advertising in our ever-growing on-line world. The consequences of the internet for our everyday lives have not been completely captured by research, and recent news on how U.S. elections were influenced by Facebook advertisement pose many questions that still need to be researched. As Androutsopoulos (2016, p. 283) states, "language and media issues are an emerging theme but do not represent canonical knowledge," while he calls for a study of "the voicing of social identities and intergroup relations in media performance." Using the term "mediation” from Agha (2007) and observing the space created by social media, literature can use social media and analyze it as the semiotic means by which people relate. While ethnography is a cocktail of methodologies that share the assumption that personal engagement with the subject is the key to understanding a social setting (Hobbs 2011, p. 101), netnography is participant-observational research based in online hanging-out, download, reflection and connection.

For this project I transcribed and closely analyzed several pieces of discourse to uncover mechanisms of semiotic meaning-making strategies. Furthermore, my analysis aims to answer questions of sociocultural nature related to the context in which the discourse is performed. Data was collected on the use of social media to construct new spaces for interaction during the year of 2016.

The data comes from active Latina supporters of the Donald J. Trump presidential campaign of 2016. The candidate sympathizers became/got organized through social media and offered a few interviews through other means of communication in order to establish their support. Furthermore, two Hispanic women created the active political movement Latinas for Trump and several other movements were created in social media. All of them were active through their social media accounts such as Twitter and Facebook. The interest on the role of Facebook in the creation of discourse has been recognized in a recent study by Allcott and Gentzkow (2017). Their statistical analysis shows that the sharing of fake information through Facebook played an important role in the 2016 election, and that $14 \%$ of Americans call social media "their most 
important source of information" (Allcott \& Gentzkow 2017, p. 31). Kozinets (2015) classifies this kind of groups as the "tight social networks" where the deep connections between users reinforces the kind of communication portrayed on it. In the next sections I will explore how these different models of communication are demonstrated in diverse ways when dealing with ethnopolitical categories on social media.

\section{Semiotic processes of identification}

\subsection{The fluidity of ethnicity}

The iconization of US Latinos (Irvine \& Gal, 2000; Hill, 2008) has been previously recognized in the literature, reaching its most public platform during the presidential campaign of president Donald Trump. In June 2016, the thenpresidential candidate started a long chain of verbal attacks on the Hispanic communities. The list of offensive comments directed towards this minority is quite long; here, I provide only the first few controversial statements:

1. When Mexico sends its people, they're not sending their best. They're not sending you.

2. They're not sending you. They're sending people that have lots of problems, and they're

3. bringing those problems with us. They're bringing drugs. They're bringing crime. They're

4. rapists. And some, I assume, are good people." (He later added) "It's coming from more

5. than Mexico. It's coming from all over South and Latin America ... (Trump, cited in Kopan, 2016)

When the then-candidate made these derogative remarks, followed by many others, regarding Mexico and its people, the racist discourse of the Latino Threat was brought to public and open stages. These statements point to very negative associations and indexicalizations of Hispanics as rapists, drugdealers and killers. Furthermore, by pointing at a mainly white population in the audience, as seen in the video, and saying twice They're not sending you (lines 1 and 2), he makes specific reference to who belongs to the group he considers good people. Thus, the intertextuality of his remarks are implicit by the situation in which he states such words. Trump adds that he assumes some are good people, but by adding the verb of assumption he implies he does not know anyone from Mexico, South and Latin America that are good people, thus, doubting this is a real possibility.

Clearly, these comments caused a severe reaction from all over the nation and the world. Many businesspeople decided to stop doing business with the candidate, and he was harshly criticized by a large part of the population and 
the government. However, some supporters decided to ignore these comments and continue to support him, as shown by the fact that $29 \%$ of Latinos voted for Trump and 65\% for Mrs Hilary Clinton, while in 2012, $27 \%$ Latinos voted for Mitt Romney and $71 \%$ for Barack Obama. When comparing the numbers of the 2012 campaign, several journalists expressed their disappointment, given the expectation that the then-presidential candidate's remarks were supposed to be the "bucket of cold water that aroused the sleeping giant" (Suro 2016). However, such assumption is based on the presummed strategic "civic cohesion" that unites Latino voters and that is largely problematic and inaccurate (Beltran, 2010). The idea behind the Latino vote is mainly based on the racialized "otherness" as a distinctive group with one common ideal that could potentially change the course of elections. In this case, it was expected that all Latinos would halt the Republican candidate's access to the presidency. Yet, in the 2016 campaign, many US Latinos decided to publicly support Donald Trump.

In the following sections of this analysis I explore processes of identity construction that go beyond merely accepting or contesting an ideology, examining instead the ways in which individuals contruct meaning. I will specifically look closely at semiotic resources or processes of meaning making that involve the study of linguistic signs (Kress, 2008).

In April 2016, two Hispanic women, Ileana Garcia and Denise Galvez (in the transcription as I and D respectively), created the group Latinas for Trump. These two middle-aged women from the state of Florida were active and vocal on several platforms during the presidential campaign. When Garcia was interviewed and questioned on the reasons why they had created the group, she claimed the following:

6. I:I'd like to remind everyone that he [Trump] won 66 out of 67 counties in Florida, which

7. is primarily Hispanic so it all depends on what you call Hispanic. You know a lot of

8. Hispanics consider ourselves Americans first, so I think that there's a lot of confusion in

9. regards to that (Gamboa, 2016; transcribed from videos posted on social networks, italics added).

In this statement, Garcia positions herself first as an American (line 8). Using Brubaker's terminology and strategy for the study of identity (Brubaker, 2004)?, we see that Garcia links her support for Trump to her self-representation as an American. Thus, she supports her decision based on what can be considered as the most privileged position, e. g. being American, and relegates her Hispanic heritage to a second position. In this way, she also forms a commonality and a bond with those other Americans that support the ideologies pushed by Donald Trump, that of America first. We see this categorization by Garcia when she mentions that she is not the only one who thinks that way. To accomplish this, 
she uses the first person plural to include a larger population that supposedly thinks the same way (line 8). Garcia further explains:

10. When I saw that, that there were people that were unfriending people, and were

11. threatening other people because they liked Donald Trump. It was like 'no, this is crazy,

12. this is something that you see in a 3rd world country, in a communist country. This

13. can't possibly be happening in my United States.' (Gamboa, 2016).

Notice the use of threatening in this sentence. Even though Garcia uses the same word, "people," for supporters and non-supporters of the candidate, the people who are threatening (line 11) others are those who do not like Donald Trump. In a clear example of intertextuality (Gal, 2001; Briggs \& Bauman, 1992), the use of this verb relates to the idea of immigrants as a threat to the nation, thus reinforcing the semantic field of the violent other. It is also interesting that Garcia talks about a 3rd world country and a communist country (line 12); the correlation between these two ideas could be a result of her views on non-democratic governments such as Cuba, but at the same time Garcia emphasizes that her country, my country (line 12), is the United States. Thus, it seems clear that Garcia explains her support for Donald Trump based on her own self-representation and categorization as someone who belongs to that you (line 1 and 2 above) that Trump refers to.

\subsection{Constructing identities on social media}

Since this group was also active on social media, I frequented this and other Facebook groups and some of its followers to explore the construction of identity in social media. This proved particularly interesting in the case of the presidential election, given that the role of Facebook in granting the victory to Donald Trump was all over the media after his victory. Researchers and journalists have found correlations between the use of social media, the sharing of fake news, and the candidate's victory. A study by Gutierrez-Rubi (in Faus, 2016) has suggested that Trump's presence on Facebook was a determining factor of his victory.

Figure 1 above was seen as the cover of a Facebook profile. The owner, a Mexican woman who immigrated as a young adult to the United States, was a very active member of the online community of Trump supporters. Looking at the picture, it caught my attention that a person with her background and living in the Southwest was replicating this particular slogan. The statement to take our country back stated by someone of Mexican origin could be well making reference to the history of the Southwest and the notion that Mexicans were wrongfully stripped of their land. Chavez (2008) suggests that the idea of a Mexican reconquest of the U.S. Southwest is behind the construction of the Latino Threat discourse as well. 


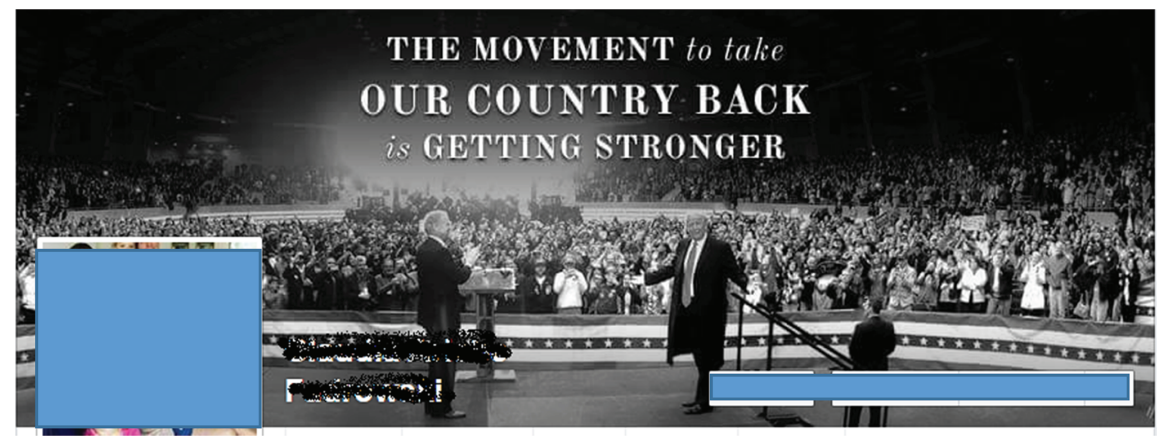

Figure 1: Profile Facebook picture from one of the research subjects.

However, this is not the case for this picture. Instead, the adoption of this particular statement, with the first plural possessive pronoun, our country, suggests that she identifies as a part of the group whose real ownership of the nation commonly referred to as America has never been doubted by the president.

It is here where, at a superficial glance, the contradiction of someone with her immigration background supporting a statement like taking our country back seems particularly telling. Using the tools mentioned earlier, we understand that ethnopolitical categories are imposed, and that people can actively choose their own subject positionings within the different ideologies that construct our world. Thus, this person is positiong herself as part of the in-group. Not taking for granted this person's ethnicity, and instead looking at how indidviduals construct their own processes of identification is the only way we can really understand what the picture above, in this context, conveys.

Furthermore, this person was also part of a Facebook group called Latinos/ Hispanics for Trump, that has more than 35,000 followers. The picture posted on election day can be seen below in Figure 2, on the left. The words Introducing our new President and First Lady can be read under God Bless America! At first glance I hypothesized that the use of the first person plural was due to a complete assimilation to the American culture and lack of identification with Hispanic origins. However, given that the group is specifically called Latinos/Hispanics for Trump and given the caption found in Figure 2, on the right. I argue that the categorization process seems to be a little bit more complicated than that.

The chart shown in Figure 2, a post from November 2016, the creator shows how the number of supporters has increased since its creation in 2015, and has reached more than 30,000 'likes.' The caption at the bottom emphasizes what the author sees as the reason for the growing number of supporters to the page, and what unites them as a group. The author emphasizes that they are traditionally very conservative 


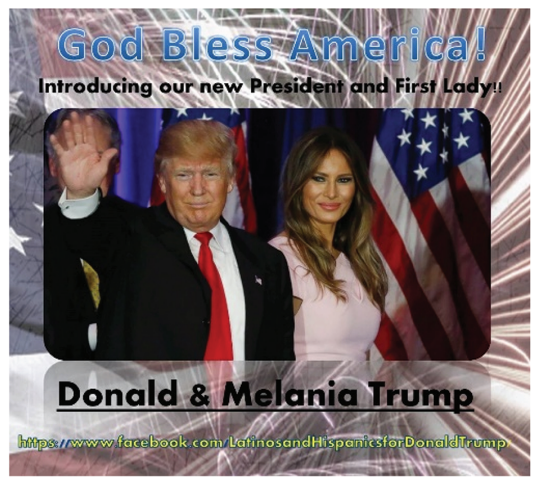

\section{0,000 'Likes' and Climbingl!}

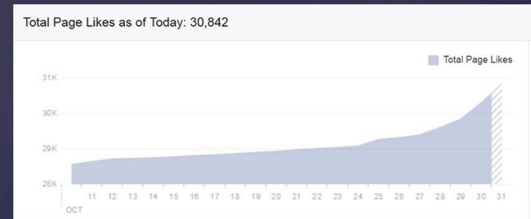

Hispanic/Latino Americans are traditionally very conservative and family oriented. Amazing and growing support for Donald J. Trump!!

Figure 2: Posts from the group Latinos/Hispanicss for Trump.

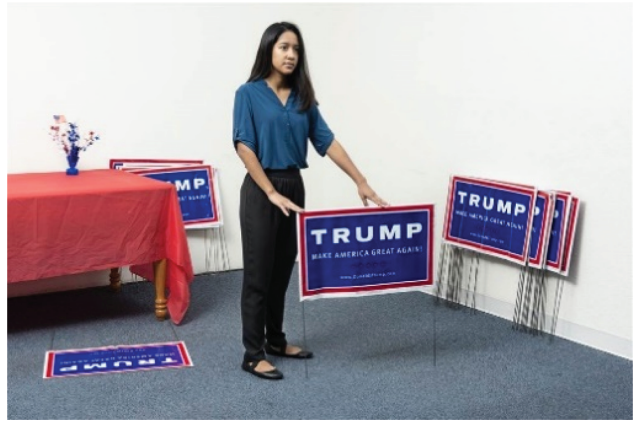

Figure 3: Jimena Rivera holding signs for the Trump campaign.

and family oriented, choosing to highlight that these two aspects of Latino culture separates the group and those who follow them from non-conservative and nonfamily oriented others and, at the same time, by being a part of this group they actively identify themselves as part of the in-group that Trump references. That is, even if they are Mexicans (or Hispanics) they are not part of that other group Trump calls rapists and criminals, because they are conservative and family-oriented.

\subsection{The female body and antiabortion discourses}

The use of conservative narratives as the basis for supporting Trump leads me to my last point. Many women who support Donald Trump have mentioned that, while they agree that some of his comments are inappropiate, their support 
remains with him because of the things he would do if elected president, such as appointing a new Supreme Court Justice. Because the reproduction of a discourse is another semiotic process of meaning-making, in this section I will examine the adoption and reproduction of a particular discourse, the debate on abortion as part of the discourses surrounding the female body. When Denise Galvez, co-creator of Latinas for Trump, was interviewed in regards to Trump's lewd and sexist comments she claimed the following:

1. Reporter: I just got to ask you after all these revelations, do you still support Donald

2. Trump? or? would you prefer he stepped aside, and whatever the answer, why?

3. D: I mean, the majority of us don't condone what he says. Let's get that clear. We don't

4. want people talking about that, you know, in front of our daughters, for instance, my

5. daughters. But we also acknowledge that he said it in private, okay? He said it

6. amongst men, we know that it's just talk, it's banter. It's not reflective of his actions

7. and who he is, and we rather focus on policy, ideology, and for those reasons, things

8. like the Supreme Court Justice, you know? Choosing that person. That's more

9. important to us, and that's where we focus our energy (Fahrenthold, 2016; transcribed from videos posted on social networks, italics added).

As seen from this brief excerpt, people choose the narratives that are more related to their own views. Galvez minimizes the importance of Trump's comments by stating that they were made in private and amongst men (line 6), also classifying the comments as just talk and banter (line 6). Although the reporter specifically inquires about Galvez's opinion, I just got to ask you (line 1), Galvez never uses the first person singular pronoun "I" to respond. Instead, she uses the first person plural pronoun "we," "us," eight times in a 30 second excerpt. This way, Galvez frames her opinion within the support of a group. By adopting discursive positions, Galvez manages to position herself as part of the in-group.

However, what I find particularly interesting in this excerpt is her comment where we focus our energy (line 7). Galvez recognizes that they prefer to overlook offensive and sexually abusive behavior because of a larger purpose: The Supreme Court Justice, choosing that person (line 8). Choosing a conservative Supreme Court Justice has a lot of implications for decisions that will determine the future of gun control and abortion issues among others. For many supporters, appointing a more conservative office was the main reason to support Trump. As Molina Guzman (2007) points out, women's bodies constitute the place where the nation is biologically reproduced and symbolically maintained. Generally speaking, the bodies of women of color are "controlled, patrolled and ideologically disciplined through legal and cultural practices” (Barrera 2002, in Molina Guzman, 2007, p. 118). In the United States, Latinas are hypersexualized and their fertility practices considered as transgressive of normal practices. 
Therefore, adopting discourses of discipline on women's bodies becomes for many an ideological way of constructing the nation. I argue that it is based on the adoption of the anti-abortion discourse that many people supported Donald Trump's candidacy regardless of other opinions. See for example the comments made by Jimena Rivera, a Mexican immigrant who bases her choice of preference on her antiabortion views.

1. Jimena Rivera - Laredo, Texas. I was born in Matamoros, Tamaulipas, Mexico. There is

2. a lot of irony in the fact that I care about U.S. politics when I can't even vote there. I owe

3. it a lot. The United States has always prided itself on being a nation of freedom. Although

4. I can't vote for him, I do support Donald Trump. I believe he has grown during his

5. campaign as a person. He is not without flaws, but he stands for what I value most. The

6. issue I see as most important is the issue of abortion. Abortion is really about how a

7. person sees and values another human life. Trump has declared himself to be pro-life. He

8. is running under a party that is also pro-life. That is enough to gain my support (Rivera in

9. Los Trumpistas ..., 2016).

Rivera recognizes that he is not without flaws (line 5), but because he stands for what she values most, a ban on abortion, she still supports the candidate. Although Rivera does not use the inclusive first person plural pronoun to talk about the U.S. - given the fact that non-citizens cannot vote - she positions herself within the in-group by categorizing her opinion within one of the most mainstream views of those who supported Donald Trump, anti-abortion. Rivera also distances herself from the "the nonnormative, stigmatized, high-fertility" of Latinas and the sexual behavior that produced it” (Chavez, 2008, p. 74). Acknowledging the hypersexualization of US Latinas, Rivera chooses to not self-represent as an outcast, and thus along the more normative and conservative views. While Rivera may come from a conservative background, and her beliefs on abortion may have deeper roots, the fact that she chooses this particular discourse to back her support of Donald Trump is particularly telling. Through the adoption of a US mainstream narrative, Rivera identifies with the most normative and mainstream views on the issue, i. e. not belonging to the nonnormative group of sexually-oriented Latinas. It is through the adoption of normative discourses individuals in the minorities construe themselves as part of what they consider the mainstream society.

The pro-life narrative continues to be publicly manifested even when based on misconceptions and wrong terminology. The few times that president Trump mentioned the issue of abortion during the presidential campaign, he did it by using incorrect information on the types of abortions that can be carried out and the procedures. However, even if using incorrect information, Trump managed to position himself within the antiabortion narratives by stating that he would 
appoint pro-life Supreme Court Justices. Thus, illegalizing abortion has become emblematic for many women that decided to vote for Trump, even if it is based on incorrect medical narratives:

1. You can take the baby and rip the baby out of the womb of the mother just prior to the

2. birth of the baby. Now, you can say that that is OK, and Hillary can say that that is OK,

3. but it's not OK with me (Trump, cited in Mangan, 2016).

The procedure Trump described during the presidential debate was a ceasarean birth, because none of the abortion procedures work this way. However, the important thing to notice in this paper is that people adopted Trump's narrative, even if based on misconceptions. Supporters of Donald Trump use the antiabortion discourse to defend his argument, even if referring to a different process. In a social media post, a person posted a web site showing instruments used in partial birth abortion. Schoen (2015, p. 22) argues that calling the procedure partial birth abortion has become a "political term, designed to raise the impression that the procedure, intact D\&E, ${ }^{2}$ is performed moments before term delivery."

In the following post and comments found on social media (Figures 4) we see that many female Trump supporters are using the same narrative of

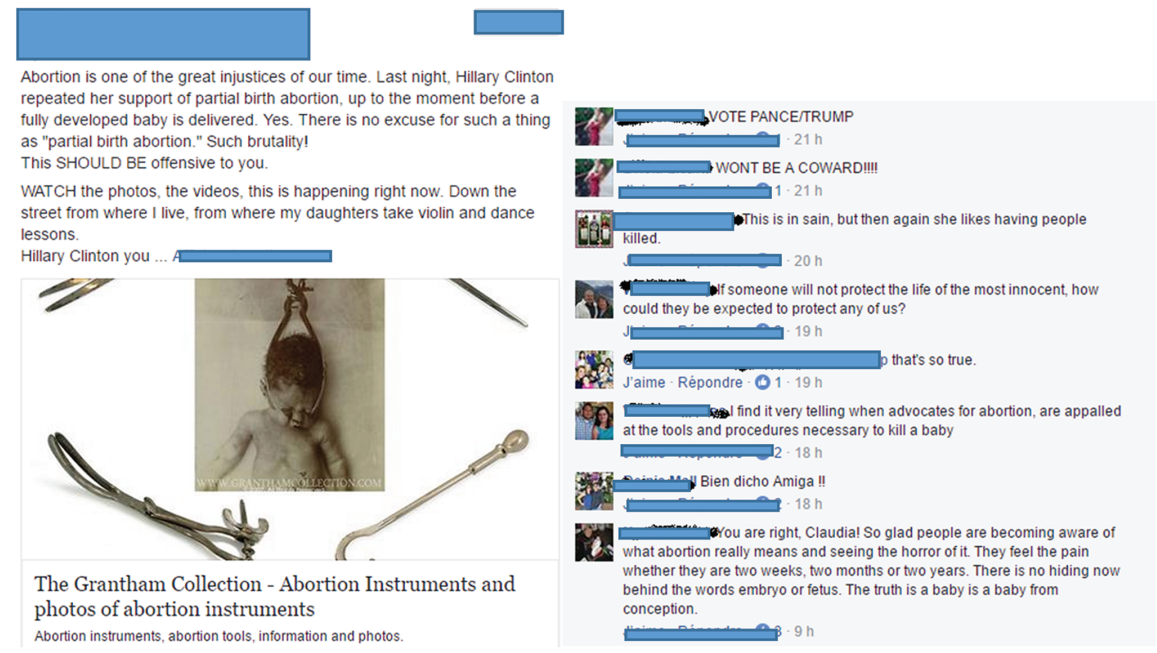

Figure 4: Posts and comments on abortion.

2 D\&E: Dilation and Evacuation. A process that includes a complete removal of the tissue inside the uterus, carried out in the second trimester and recommended for women diagnosed with fetus with severe abnormalities and medical problems. 
antiabortion movements. Even when the procedure mentioned by Trump demonstrates his lack of knowledge on the topic, the online user adopts the term partial birth abortion in a completely politicized way. In this way, providers and facilitators are killers and fetuses are babies from the moment of conception, with statements like They feel the pain whether they are two weeks, two months or two years (Figure 4) and the fact that the page is titled procedures necessary to kill a baby (Figure 4). The person who wrote this post highlights that the brutality of partial birth abortion SHOULD BE offensive to you. She uses the second person addressing the people in her social network, as a feeling that should be shared amongst her social media group.

We even see comments stating Hillary Clinton is a killer, a narrative pushed forward by Trump himself: this is in sain (sic), but then again she likes having people killed (Figure 4). This post was public and shared to the whole Facebook community; however, I have chosen to hide their names due to ethical concerns. I personally know some of the people in this post and I can attest that everyone who commented on this image has some Hispanic background, also shown in one of the comments in Spanish to agree with the post: Bien dicho, Amiga [Well said, my friend] (Figure 4). As mentioned earlier, this group of people may have had conservative views preceding the 2016 presidential campaign. However, my interest lies on why they choose this discourse to support Trump's candidacy. I argue that US Latinas encounter daily the gender expectations constructed by US media and politics, such as the scrutiny of their private life, the label of sexually deviant others and the stigmatized nonnormative fertility rates, thus, making a stance against abortion is seen as an act of defiance of the stereotype and the ethnopolitical categories they are subjected to.

In this way, these individuals are replicating the narratives surrounding abortion that have been pushed forward in the last decade, i. e. "in the context of abortion, narratives were most important in situating a person vis-à-vis abortion: as participant and actor or victim and object” (Schoen, 2015, p. 21). In the comments above, people of Hispanic origins have adopted the same narrative of the most conservative and religious discourses. Thus, I argue that it is precisely through the adoption of these narratives, that individuals belonging to the minorities position themselves as part of the in-group. To this extent, even when society and particularly powerful individuals classify them as part of the out-group, i. e. the foreigner, they adopt narratives that position them as part of the mainstream. In this way, they actively construct subject-positions (Hall, 2012) that go beyond their ethnicity and their gender. Through discourse, they actively identify as part of the America Trump references in his speech, and as such they also take part in the construction of the other. 


\section{Conclusion}

In this analysis, I examined the ways in which people construct their identities by positioning their self among existing narratives and reconstructing them. I have observed several semiotic mechanisms through which individuals (i) identify, (ii) construct their own self-representation and (iii) look for commonalities to become part of a group (Brubaker, 2004). Because being part of a group necessarily involves rejecting and categorizing those not in your group as the other, this creates connections through which we interact with people. For Trump, Hispanics and women are not part of his in-group. However, both women and Hispanics have found their own ways to approach these imposed categorizations and reject them not based on their ethnicity or gender, but based on reimagined and reconstructed discourses and ideologies constructed through language. Thus, having reviewed these pieces of data, I claim that all linguistic performances of subject positions cannot be understood without taking into account their relationship to ethnopolitical categories, and that it is crucial to understand the language mechanisms that Latinas in the United States use to relate to ethnopolitical categories of gender and ethnicity. Finally, I also advocate for more research that analyzes social networks as a medium of expression and where ideologies are constructed and reimagined.

\section{References}

Acosta-Belén, E., and Santiago, C. E. (1998). Merging Borders: The Remapping of America. In A. Darder, and R. D. Torres editors The Latino Studies Reader: Culture, Economy and Society (29-42). Malden, MA: Blackwell Publisher.

Agha, A. (2007). The Object Called "Language” and the Subject of Linguistics. Journal of English Linguistics (35) 3, 217-235.

Allcott, H., and Gentzkow, M. (2017). Social Media and Fake News in the 2016 Election. Journal of Economic Perspectives (31) 2, 211-236.

Androutsopoulos, J. (2016). Theorizing Media, Mediation and Mediatization. In N. Coupland editor Theoretical Debates in Sociolinguistics (282-302). Cambridge: Cambridge University Press.

Barrera, M. (2002). Hottentot 2000: Jenifer Lopez and Her Butt. In K. Phillips and B. Reay editors Sexualities in History: A Reader (411-417). New York: Routledge.

Beltran, C. (2010). The Trouble with Unity. New York: Oxford University Press.

Briggs, Charles L. \& Bauman, R. (1992). Genre, Intertextuality and Social Power. Journal of Linguistic Anthropology 2, 131-172.

Brubaker, R. (2004). Ethnicity without Groups. Cambridge, MA: Harvard University Press. 
Bucholtz, M. (2011). White Kids, Language, Race, and Styles of Youth Identity. New York: Cambridge University Press.

Chavez, L. R. (2008). The Latino Threat. Stanford: Stanford University Press.

Dávila, A. (2001). Latinos, Inc. The Marketing and Making of a People. Berkeley and Los Angeles: University of California Press.

Fahrenthold, D. A. (2016, October 8). Trump recorded having extremely lewd conversation about women in 2005. Retrieved from https://www.washingtonpost.com/politics/trumprecorded-having-extremely-lewd-conversation-about-women-in-2005/2016/10/07/ 3b9ce776-8cb4-11e6-bf8a3d26847eeed4_story.html?utm_term=.d5cd3cf76517

Faus, J. (2016, December 7). Tiene Facebook la clave del éxito electoral de Trump? Retrieved from http://internacional.elpais.com/internacional/2016/12/06/mundo_global/ 1481046974_198482.html

Gal, S. (2001). Language, Gender and Power: An Anthropological Review. In A. Duranti editor Linguistic Anthropology: A Reader (420-430). Malden, MA: Blackwell Publishers.

Gamboa, S. (2016, July 17). Founder of Latinas For Trump: Latinos Will 'Put Him Over the Top'. Retrieved from: http://www.nbcnews.com/news/latino/founder-latinas-trump-latinos-willput-him-over-top-n611281

Hall, S. (2012). Foucault: Power, Knowledge and Discourse. In M. Whetherell, S. Taylor, and S. Yates editors Discourse Theory and Practice, a reader (72-81). London: SAGE.

Hill, J. H. (2008). The Everyday Language of White Racism. Malden, MA: Wiley-Blackwell.

Hobbs, D. (2011). Ethnography in context. London: SAGE.

Irvine, J. T., and Gal, S. (2000). Language Ideology and Linguistic Diferentiation. In P. V. Kroskrity editor Regimes of Language: Ideologies, Polities, and Identities (35-83). Santa Fe: School of American Research Press.

Kopan, T. (2016, August 31). What Donald Trump has said about Mexico and vice versa. Retrieved from: http://www.cnn.com/2016/08/31/politics/donald-trump-mexico-statements/

Kozinets, R. (2015). Netnography Redefined. California: SAGE Publications.

Kress, G. (2008). From Saussure to Critical Linguistic: The Turn towards a Social View of Language. In S. T. M. Whetherell editor Discourse Theory and Practice: A Reader (29-38). London: SAGE Publications.

Levinson, L. (2016, November 30). More than half of white women in the US voted for Trump, but why? Popsugar News. Retrieved from : http://www.popsugar.com/news/WhatPercentage-White-Women-Voted-Trump-42690419

Los Trumpistas: Meet Latinos Supporting Trump. (2016, September 16). Retrieved from: http:// www.nbcnews.com/slideshow/los-trumpistas-meet-latinos-supporting-trump-n649131

Mangan, N. (2016, October 19). Trump: I’ll appoint Supreme Court justices to overturn Roe v. Wade abortion case. CNBC. Retrieved from https://www.cnbc.com/2016/10/19/trump-illappoint-supreme-court-justices-to-overturn-roe-v-wade-abortion-case.html

Mendible, M. (2007). From Bananas to Buttocks. The Latina Body in Popular Film and Culture. Austin: University of Texas Press.

Molina Guzman, I. (2007). Salma Hayek's Frida: Transnational Latina Bodies in Popular Culture. In M. Mendible editor From Bananas to Buttocks: The Latina Body in Popular Film and Culture (p. 219-241). Austin: University of Texas Press.

Roe v. Wade. (1973). 410 U.S. 113.

Santa Ana, O. (2002). Brown Tide Rising. Austin: University of Texas Press.

Schoen, J. (2015). Abortion after Roe. Chapel Hill The University of North Carolina Press. 
Suro, R. (2016, January). Here's what happened with the Latino vote. The New York Times. Retrieved from https://www.nytimes.com/interactive/projects/cp/opinion/election-night2016/heres-what-happened-with-the-latino-vote

Woolard, K. (2008). Language and Identity Choice in Catalonia: The Interplay of Contrasting Ideologies of Linguistic Authority. In U. M. Kirsten Süselbeck editor Lengua, Nación e Identidad: La Regulación del Plurilingüismo en España y América Latina (303-323). Madrid: Iberoamericana. 